\title{
Synthesis of Dimeric Cinnamoylamide Derivatives and Evaluation of Their Depigmenting Activities
}

\author{
Myung Kyoo Kim, Hyun Soo Youk, Jae Jin Yoo, Soo Mi Ahn, ${ }^{\dagger}$ Ho Sik Rho, ${ }^{\ddagger}, *$ \\ Ji Hoon Ha, ${ }^{\S}$ Jun Pil Hwang, ${ }^{\S}$ and Soo Nam Park ${ }^{\S, *}$ \\ Samkyung Costech Co., Ltd., Suwon 443-734, Korea \\ ${ }^{\dagger}$ Kyung Hee University Skin Biotechnology Center, Suwon 443-270, Korea \\ ${ }^{*} R$ \& D Center, AmorePacific Corporation, Yongin 446-729, Korea. *E-mail: thiocarbon@hanmail.net \\ ${ }^{\S}$ Department of Fine Chemistry and Cosmetic R\&D Center, Seoul National University of Science and Technology, \\ Seoul 139-743, Korea. *E-mail: snpark@seoultech.ac.kr \\ Received April 22, 2014, Accepted June 5, 2014
}

Key Words : Dimeric cinnamoylamide, Melanin, Depigmentation, Tyrosinase

Human skin color is primarily determined by melanin production. Melanin is a biopigment synthesized by melanocytes in a specialized cellular organelle called the melanosome. ${ }^{1}$ Synthesized melanin is transferred from melanocytes to keratinocytes in the human epidermis. Melanin is located in the outer layer of the skin and protects against the harmful effects of ultraviolet (UV) irradiation. However, overproduction of melanin and its abnormal accumulation in human skin causes a variety of cosmetic and clinical problems. ${ }^{2}$ Melanin synthesis is a complex process that involves enzymatic and chemical reactions. Among the enzymes involved in melanin synthesis, tyrosinase is the most critical and rate limiting enzyme. Tyrosinase $\mathrm{e}^{3}$ is a copper-containing enzyme that catalyzes two distinct reactions involved in melanin synthesis; the hydroxylation of L-tyrosine to L-dopa and the subsequent oxidation of L-dopa to dopaquinone. Therefore, tyrosinase inhibitors have attracted attention as important agents for use in cosmetic and medicinal products to promote skin whitening or brightening. To date, several tyrosinase inhibitors, such as hydroquinone, ${ }^{4}$ rucinol, ${ }^{5}$ arbutin, ${ }^{6}$ kojic acid $^{7}$ and its derivatives, ${ }^{8}$ have been developed. Although hydroquinone and rucinol show potent depigment-<smiles>COc1cc(/C=C/C(=O)NCCCCNC(=O)/C=C/c2ccc(O)c(OC)c2)ccc1O</smiles>

$N, N^{\prime}$-diferuloyl-putrescine (1) ing activity, their cosmetic applications are limited because of side effects. ${ }^{9}$ Kojic acid and arbutin are widely used in cosmetics. However, their depigmenting activities are unsatisfactory, and a high dosage (around $2 \%$ ) is required for their efficacy in formulations. Thus, there is a strong need for effective and safe depigmenting agents. Phenolic compounds, such as benzoic acid, cinnamic acid and its derivatives, have been reported to act as tyrosinase inhibitors. ${ }^{10}$ Recently, dimeric cinnamoylamide derivatives were isolated from sophora japonica ${ }^{11}$ and synthesized as depigmenting agents. ${ }^{12}$ $N, N^{\prime}$-diferuloyl-putrescine (1) showed potent tyrosinase inhibitory activity in human melanocytes. The presence of hydroxyl groups at the para position is considered a fundamental requirement for alternative tyrosinase substrates.

Here, we synthesized dimeric cinnamoylamide derivatives (2a-2l), containing hydroxyl groups at various positions and different diamide linkage chain lengths, and we evaluated their depigmenting activities in B16/F1 melanoma cells.

The synthetic pathway of $N, N^{\prime}$-dicoumaroyl-putrescine (2a) is shown in Scheme 1. Coumaric acid (3) was reacted with acetic anhydride in the presence of triethylamine $\left(\mathrm{Et}_{3} \mathrm{~N}\right)$ and a catalytic amount of dimethylaminopyridine (DMAP)<smiles></smiles>

2a-2d<smiles>[R]c1ccc(/C=C/C(=O)NCCCNC(=O)/C=C/c2ccc([R])cc2)cc1</smiles><smiles>[R]c1ccc(/C=C/C(=O)NCCNC(=O)/C=C/c2cccc([R])c2)cc1</smiles>

Figure 1. Structures of dimeric cinnamoylamide derivatives. 
<smiles>CC(=O)Oc1ccc(/C=C/C(=O)NCCCCNC(=O)/C=C/c2ccc(OC(C)=O)cc2)cc1</smiles><smiles>O=C(/C=C/c1ccc(O)cc1)NCCCCNC(=O)/C=C/c1ccc(O)cc1</smiles>

Scheme 1. Reaction conditions: (a) acetic anhydride, $\mathrm{Et}_{3} \mathrm{~N}$, DMAP (cat), THF; (b) $\mathrm{SOCl}_{2}$, reflux; (c) 1,4-diaminobutane, Et ${ }_{3} \mathrm{~N}$, methylene chloride; (d) $\mathrm{KOH}, \mathrm{H}_{2} \mathrm{O}$.

in tetrahydrofuran (THF) to afford acetoxy coumaric acid (4). ${ }^{12}$ Acetoxy coumaric acid (4) was refluxed in thionyl chloride $\left(\mathrm{SOCl}_{2}\right)$ to afford acid chloride, which was immediately reacted with 1,4-diaminobutane to produce the corresponding diamide (5). The hydrolysis of compound (5) afforded the desired final product, $N, N^{\prime}$-dicoumaroyl-putrescine (2a).

The inhibitory activities of dimeric cinnamoylamide derivatives on mushroom tyrosinase and their radical scavenging activities were investigated using kojic acid as a positive control (Table 1).

Tyrosinase inhibitory activities were evaluated by measuring the transformation rate of L-tyrosine to L-dopaquinone. Compounds 2a (4-hydroxy and diaminobutyl groups) exhibited a better inhibitory activity $\left(\mathrm{IC}_{50}=32.1 \mu \mathrm{M}\right)$ against tyrosinase than kojic acid $\left(\mathrm{IC}_{50}=52.2 \mu \mathrm{M}\right)$. However, compound $\mathbf{2 b}$ (3-hydroxy) and $\mathbf{2 c}$ (2-hydroxy) displayed no inhibition at $400.0 \mu \mathrm{M}$. Interestingly, compound $2 \mathrm{~d}$ (2,4dihydroxyl groups) was a potent inhibitor of tyrosinase activity $\left(\mathrm{IC}_{50}=0.82 \mu \mathrm{M}\right)$. Similar effects were observed for diaminopropyl derivatives (2e-2h) and diaminoethyl deriva-

Table 1. Mushroom tyrosinase and 2,2-diphenyl-1-picrylhydrazyl (DPPH) inhibitory activities of dimeric cinnamoylamide derivatives (2a-2l)

\begin{tabular}{cccc}
\hline Compounds & $\mathrm{R}$ & Tyrosinase $\left(\mathrm{IC}_{50}{ }^{a}\right)$ & $\mathrm{DPPH}\left(\mathrm{IC}_{50}{ }^{a}\right)$ \\
\hline $\mathbf{2 a}$ & $4-\mathrm{OH}$ & $32.1 \mu \mathrm{M}$ & $>400.0 \mu \mathrm{M}$ \\
$\mathbf{2 b}$ & $3-\mathrm{OH}$ & $>400.0 \mu \mathrm{M}$ & $>400.0 \mu \mathrm{M}$ \\
$\mathbf{2 c}$ & $2-\mathrm{OH}$ & $>400.0 \mu \mathrm{M}$ & $>400.0 \mu \mathrm{M}$ \\
$\mathbf{2 d}$ & $2-\mathrm{OH}, 4-\mathrm{OH}$ & $0.82 \mu \mathrm{M}$ & $144.4 \mu \mathrm{M}$ \\
$\mathbf{2 e}$ & $4-\mathrm{OH}$ & $6.4 \mu \mathrm{M}$ & $>400.0 \mu \mathrm{M}$ \\
$\mathbf{2 f}$ & $3-\mathrm{OH}$ & $>400.0 \mu \mathrm{M}$ & $>400.0 \mu \mathrm{M}$ \\
$\mathbf{2 g}$ & $2-\mathrm{OH}$ & $>400.0 \mu \mathrm{M}$ & $>400.0 \mu \mathrm{M}$ \\
$\mathbf{2 h}$ & $2-\mathrm{OH}, 4-\mathrm{OH}$ & $0.078 \mu \mathrm{M}$ & $246.3 \mu \mathrm{M}$ \\
$\mathbf{2 i}$ & $4-\mathrm{OH}$ & $16.3 \mu \mathrm{M}$ & $>400.0 \mu \mathrm{M}$ \\
$\mathbf{2 j}$ & $3-\mathrm{OH}$ & $>400.0 \mu \mathrm{M}$ & $>400.0 \mu \mathrm{M}$ \\
$\mathbf{2 k}$ & $2-\mathrm{OH}$ & $>400.0 \mu \mathrm{M}$ & $>400.0 \mu \mathrm{M}$ \\
$\mathbf{2 l}$ & $2-\mathrm{OH}, 4-\mathrm{OH}$ & $0.034 \mu \mathrm{M}$ & $92.8 \mu \mathrm{M}$ \\
\multicolumn{2}{c}{ Kojic acid } & $52.2 \mu \mathrm{M}$ & $>400.0 \mu \mathrm{M}$ \\
\hline
\end{tabular}

${ }^{a}$ Values were determined from logarithmic concentration-inhibition curves and represent the mean of three experiments. tives (2i-2l). 4-Hydroxyl compounds (2e and $\mathbf{2 i}$ ) also displayed tyrosinase inhibitory activities, $\left(\mathrm{IC}_{50}=6.4\right.$ and 16.3 $\mu \mathrm{M}$, respectively). Compound $\mathbf{2 h}$ (2,4-dihydroxy and diaminopropyl groups) showed potent inhibitory activity $\left(\mathrm{IC}_{50}\right.$ $=0.078 \mu \mathrm{M})$. Among the tested compounds, compound $4 \mathbf{I}$ (2,4-hydroxy and diaminoethyl groups) was the most potent inhibitor $\left(\mathrm{IC}_{50}=0.034 \mu \mathrm{M}\right)$, with an $\mathrm{IC}_{50}$ of approximately $1 /$ 1500 that of kojic acid $\left(\mathrm{IC}_{50}=52.2 \mu \mathrm{M}\right)$. In DPPH assays, only 2,4-dihydroxyl compounds (2d, $\mathbf{2 h}$, and $\mathbf{2 l})$ displayed inhibitory activities. These results indicate that the catechol moiety (2,4-dihydroxyl groups) is an important pharmacophore for tyrosinase inhibition and radical scavenging activity in dimeric cinnamoylamide derivatives.

Next, we investigated the depigmenting activities of dimeric cinnamoylamide derivatives (2a-2I) in B16/F1 melanoma cells (Table 2).

Initially, we assessed the cytotoxicy of each compound in B16/F1 melanoma cells. At $80 \mu \mathrm{M}$, none of the compounds produced cytotoxic effects, and kojic acid was not cytotoxic at $1 \mathrm{mM}$. Compound $\mathbf{2 a}, \mathbf{2 b}$, and $\mathbf{2 c}$, which contain monohydroxyl and diaminobutyl groups, did not display depig-

Table 2. Depigmenting activities of dimeric cinnamoylamide derivatives (2a-2l)

\begin{tabular}{ccc}
\hline Compounds & $\mathrm{R}$ & Depigmentation $\left(\mathrm{IC}_{50}{ }^{a}\right)$ \\
\hline $\mathbf{2 a}$ & $4-\mathrm{OH}$ & $>40.0 \mu \mathrm{M}$ \\
$\mathbf{2 b}$ & $3-\mathrm{OH}$ & $>40.0 \mu \mathrm{M}$ \\
$\mathbf{2 c}$ & $2-\mathrm{OH}$ & $>40.0 \mu \mathrm{M}$ \\
$\mathbf{2 d}$ & $2-\mathrm{OH}, 4-\mathrm{OH}$ & $>40.0 \mu \mathrm{M}$ \\
$\mathbf{2 e}$ & $4-\mathrm{OH}$ & $>40.0 \mu \mathrm{M}$ \\
$\mathbf{2 f}$ & $3-\mathrm{OH}$ & $>40.0 \mu \mathrm{M}$ \\
$\mathbf{2 g}$ & $2-\mathrm{OH}$ & $2.4 \mu \mathrm{M}$ \\
$\mathbf{2 h}$ & $2-\mathrm{OH}, 4-\mathrm{OH}$ & $>40.0 \mu \mathrm{M}$ \\
$\mathbf{2 i}$ & $4-\mathrm{OH}$ & $>40.0 \mu \mathrm{M}$ \\
$\mathbf{2 j}$ & $3-\mathrm{OH}$ & $>40.0 \mu \mathrm{M}$ \\
$\mathbf{2 k}$ & $2-\mathrm{OH}$ & $8.7 \mu \mathrm{M}$ \\
$\mathbf{2 l}$ & $2-\mathrm{OH}, 4-\mathrm{OH}$ & $>1 \mathrm{mM}$
\end{tabular}

${ }^{a}$ Values were determined from logarithmic concentration-inhibition curves and represent the means of three experiments. None of the compounds (2a-2l) were cytotoxic at $80 \mu \mathrm{M}$ and kojic acid was not cytotoxic at $1 \mathrm{mM}$. 
Table 3. Calculation of $\log P$ values

\begin{tabular}{ccc}
\hline Compounds & $\mathrm{R}$ & $\log \mathrm{P}^{a}$ \\
\hline $\mathbf{2 a}$ & $4-\mathrm{OH}$ & 2.57 \\
$\mathbf{2 d}$ & 2-OH, 4-OH & 1.79 \\
$\mathbf{2 e}$ & $4-\mathrm{OH}$ & 2.12 \\
$\mathbf{2 h}$ & 2-OH, 4-OH & 1.34 \\
$\mathbf{2 i}$ & $4-\mathrm{OH}$ & 2.01 \\
$\mathbf{2}$ & 2-OH, 4-OH & 1.62 \\
\hline
\end{tabular}

${ }^{a} \log \mathrm{P}(\log [$ octanol/water] partition coefficient) values were calculated using Chemdraw version 8.0.

menting activities up to a concentration of $40 \mu \mathrm{M}$. In agreement with its tyrosinase inhibitory activities, compound $\mathbf{2 d}$ (2,4-dihydroxyl groups) was a potent inhibitor of depigmenting activity $\left(\mathrm{IC}_{50}=2.1 \mu \mathrm{M}\right)$. In diaminopropyl derivatives (2e-2h) and diaminoethyl derivatives (2i-2l), $\mathbf{2 h}$ and $\mathbf{2 l}$ containing 2,4-dihydroxyl groups showed similar potent depigmenting activities with $\mathrm{IC}_{50}$ values of 2.4 and $8.7 \mu \mathrm{M}$, respectively. Our results with 4-hydroxyl derivatives (2a, 2e, and $2 \mathbf{i}$ ) confirmed previous reports ${ }^{10}$ of a discrepancy between mushroom tyrosinase and depigmenting activity. This phenomenon can be explained by two hypotheses: (i) a difference in the amino acid sequence between mushroom and human tyrosinase and (ii) different physical properties to pass through the cell membrane. However, 2,4-dihydroxyl compounds (2d, $\mathbf{2 h}$, and $\mathbf{2 l}$ ) showed potent depigmenting activities in B16/F1 melanoma cells and potent tyrosinase inhibitory activity. Thus, the addition of a 2-hydroxy group (catechol moiety) might play a critical role in changing the efficacy behavior and physical property of these compounds. To compare the hydrophobic characteristics of 4-hydroxyl compounds (2a, 2e, and 2i) and 2,4-dihydroxyl compounds (2d, 2h, and 2l), we calculated Log P values (Table 3).

Although the hydrophobic characteristics were decreased by the addition of a 2-hydroxy group, 2,4-dihydroxyl compounds (2d, $\mathbf{2 h}$, and $\mathbf{2 l}$ ) displayed potent depigmenting activity in B16/F1 melanoma cells. The potent activity of these compounds is likely due to the enhanced accessibility of the 2,4-dihydroxyl group (catechol moiety) to the active site of tyrosinase and the balance between hydrophilic and hydrophobic characteristics that improved cell penetration.

In conclusion, we synthesized dimeric cinnamoylamide derivatives (2a-2l) and evaluated their tyrosinase inhibitory and radical scavenging activities. Compounds (2a, 2e, and 2i) containing a 4-hydroxyl group showed tyrosinase inhibitory activity without radical scavenging activity. However, compounds ( $\mathbf{2 d}, \mathbf{2 h}$, and $\mathbf{2 l}$ ) containing a 2,4-hydroxyl group showed potent tyrosinase inhibitory and radical scavenging activities. In B16/F1 melanoma cells, only compounds (2d, $\mathbf{2 h}$, and 2l) showed depigmenting activity with $\mathrm{IC}_{50}$ values of $2.1,2.4$, and $8.7 \mu \mathrm{M}$, respectively. Taken together, these results indicate that the catechol moiety (2,4-dihydroxyl groups) in dimeric cinnamoylamide derivatives is an important pharmacophore for tyrosinase inhibition, radical scavenging activity, and depigmenting activity in B16/F1 melanoma cells. We are currently performing further studies on the depigmenting activities of dihydroxyl groups in different positions (2,4-, 3,5-, 3,4-, 2,5- and 2,3-) in dimeric cinnamoylamide derivatives.

\section{Experimental Section}

Synthesis of $N, N^{\prime}$-Dicoumaroyl-putrescine (2a).

Acetoxy Coumaric Acid (4): To a solution containing coumaric acid (5.2 g, $0.03 \mathrm{~mol})$, triethyl amine (7.7 g, 0.076 $\mathrm{mol}$ ), and 4-(dimethylamino)pyridine (cat) in tetrahydrofuran $(60 \mathrm{~mL})$ was added acetic anhydride $(7.8 \mathrm{~g}, 0.076$ mol). The reaction mixture was refluxed for $3 \mathrm{~h}$, and the solvent was removed at reduced pressure. The residue was dissolved in dichloromethane and washed with $\mathrm{HCl}(1 \mathrm{M})$ solution. The organic layer was dried with anhydrous $\mathrm{MgSO}_{4}$ and concentrated to produce a crude product. The resultant was purified by crystallization using dichloromethane and hexane to produce acetoxy coumaric acid $4(5.5 \mathrm{~g})$ at $85 \%$ yields. ${ }^{1} \mathrm{H}$ NMR $\left(300 \mathrm{MHz}, \mathrm{DMSO}-d_{6}\right) \delta 7.75(\mathrm{~d}, 2 \mathrm{H}, J=8.7$ $\mathrm{Hz}), 7.60$ (d, 1H, $J=15.6 \mathrm{~Hz}), 7.19$ (d, 1H, $J=8.7 \mathrm{~Hz}), 6.55$ $(\mathrm{d}, 1 \mathrm{H}, J=15.6 \mathrm{~Hz}), 2.28(\mathrm{~s}, 3 \mathrm{H}) .{ }^{13} \mathrm{C} \mathrm{NMR}(125 \mathrm{MHz}$, DMSO- $\left.d_{6}\right) \delta 168.4,166.9,151.1,142.2,131.3,128.8,121.7$, 118.7, 20.2. Ms-FAB (m/e) $207\left(\mathrm{M}^{+}+1\right)$.

$N, N^{\prime}$-Diacetoxycoumaroyl-putrescine (5): Acetoxy coumaric acid (3.9 g, $0.019 \mathrm{~mol})$ was dissolved in $15 \mathrm{~mL}$ of $\mathrm{SOCl}_{2}$ at $0{ }^{\circ} \mathrm{C}$ and refluxed for $1 \mathrm{~h}$. $\mathrm{SOCl}_{2}$ was removed in vacuo, and crude acid chloride was dissolved in $\mathrm{CH}_{2} \mathrm{Cl}_{2}$ $(10 \mathrm{~mL})$. Then, the prepared acid chloride solution was added to a solution of 1,4-diaminobutane $(0.8 \mathrm{~g}, 0.0095 \mathrm{~mol})$ and triethyl amine $(1.9 \mathrm{~g}, 0.019 \mathrm{~mol})$ in methylene chloride $(50 \mathrm{~mL})$. The reaction mixture was stirred for $2 \mathrm{~h}$ at room temperature, concentrated in vacuo and the residue was extracted with ethyl acetate $(300 \mathrm{~mL})$ and washed with water. The organic layer was dried with anhydrous $\mathrm{MgSO}_{4}$ and concentrated to produce a crude product. The resultant was purified by column chromatography using ethyl acetate and hexane to afford $N, N^{\prime}$-diacetoxycoumaroyl-putrescine $\mathbf{5}$ $(2.8 \mathrm{~g})$ at $65 \%$ yields. ${ }^{1} \mathrm{H}$ NMR $\left(300 \mathrm{MHz}, \mathrm{DMSO}-d_{6}\right) \delta$ $8.14(\mathrm{~s}, 1 \mathrm{H}), 7.60(\mathrm{~d}, 2 \mathrm{H}, J=8.7 \mathrm{~Hz}), 7.42$ (d, 1H, $J=15.6$ $\mathrm{Hz}), 7.17$ (d, 1H, $J=8.7 \mathrm{~Hz}), 6.59$ (d, $1 \mathrm{H}, J=15.6 \mathrm{~Hz}) .3 .20$ (m, 2H), $2.29(\mathrm{~s}, 3 \mathrm{H}), 1.49(\mathrm{~m}, 2 \mathrm{H}) .{ }^{13} \mathrm{C}$ NMR (125 MHz, DMSO- $\left.d_{6}\right) \delta 168.4,164.1,150.5,136.8,132.0,127.9,121,79$, 121.75, 37.7, 26.1, 20.2. Ms-FAB (m/e) $465\left(\mathrm{M}^{+}+1\right)$.

$\boldsymbol{N}, \boldsymbol{N}^{\prime}$-Dicoumaroyl-putrescine (2a). $N, N^{\prime}$-Diacetoxycoumaroyl-putrescine $(2.8 \mathrm{~g}, 0.006 \mathrm{~mol})$ was dissolved in $\mathrm{KOH}$ $(0.5 \mathrm{M})$ solution and heated to $50{ }^{\circ} \mathrm{C}$ for $30 \mathrm{~min}$. The reaction mixture was concentrated in vacuo, and ethylacetate $(100 \mathrm{~mL})$ was added, followed by $\mathrm{HCl}(1 \mathrm{M})$ solution. The organic layer was dried with anhydrous $\mathrm{MgSO}_{4}$ and concentrated to produce a crude product. The resultant was purified by column chromatography using ethyl acetate and hexane to afford $N, N^{\prime}$-dicoumaroyl-putrescine $2 \mathbf{a}(1.6 \mathrm{~g})$ at $70 \%$ yields. ${ }^{1} \mathrm{H}$ NMR (300 MHz, DMSO- $\left.d_{6}\right) \delta 9.81$ (bs, $\left.1 \mathrm{H}\right)$, $7.97(\mathrm{~s}, 1 \mathrm{H}), 7.38$ (d, 2H, $J=8.7 \mathrm{~Hz}), 7.30$ (d, 1H, $J=15.6$ $\mathrm{Hz}), 6.78$ (d, 1H, $J=8.7 \mathrm{~Hz}), 6.40$ (d, 1H, $J=15.6 \mathrm{~Hz}), 3.20$ $(\mathrm{m}, 2 \mathrm{H}), 1.46(\mathrm{~m}, 2 \mathrm{H}) .{ }^{13} \mathrm{C}$ NMR (125 MHz, DMSO-d $) \delta$ $164.6,158.1,137.8,128.5,125.3,118.1,115.1,37.7,26.2$. 
Ms-FAB $(m / e) 381\left(\mathrm{M}^{+}+1\right)$.

Mushroom Tyrosinase Assay. Mushroom tyrosinase and L-tyrosine were purchased from Sigma Chemical (Saint Louis, Missouri, USA). The reaction mixture for mushroom tyrosinase activity consisted of $150 \mu \mathrm{L}$ of $0.1 \mathrm{M}$ phosphate buffer (pH 6.5), $3 \mu \mathrm{L}$ of sample solution, $8 \mu \mathrm{L}$ of mushroom tyrosinase $(2,100$ unit/mL, $0.05 \mathrm{M}$ phosphate buffer at $\mathrm{pH}$ $6.5)$, and $36 \mu \mathrm{L}$ of $1.5 \mathrm{mM}$ L-tyrosine. Tyrosinase activity was determined by reading the optical density at $490 \mathrm{~nm}$ using a microplate reader (Bio-Rad 3550, Richmond, CA, USA) after incubation for $20 \mathrm{~min}$ at $37{ }^{\circ} \mathrm{C}$. The inhibitory activity of each sample is expressed as the concentration that inhibits enzyme activity by $50 \%\left(\mathrm{IC}_{50}\right)$.

DPPH Radical Scavenging Assay. DPPH radical-scavenging assay was carried out using the following procedure: a reaction mixture containing various concentrations of the test samples and DPPH methanolic solution $(0.2 \mathrm{mM})$ was incubated at room temperature for $30 \mathrm{~min}$ and the absorbance was measured at $517 \mathrm{~nm}$. Scavenging activity was expressed as a percent of the control DPPH solution (100\%). The synthetic antioxidant trolox and L-ascorbic acid were included as positive controls.

Cell Culture. The B16/F1 melanoma cells line was obtained from the Korean cell Line Bank (Seoul, Korea). Cells were cultured in Dulbecco's Modified Eagle medium (DMEM) containing Fetal Bovine Serum (FBS, 10\%), penicillin $(100 \mathrm{U} / \mathrm{mL})$, and streptomycin $(0.1 \mathrm{mg} / \mathrm{mL})$ at $37^{\circ} \mathrm{C}$ in a humidified atmosphere of $5 \% \mathrm{CO}_{2}$.

Measurements of Cell Viability. Cell viability was measured using the (3-(4,5-dimethylthiazol-2-yl)-2,5-diphenyltetrazolium bromide (MTT) method. Cells were plated in 96-well plates and cultured for $24 \mathrm{~h}$. After treatment with kojic acid and dimeric cinnamoylamide derivatives (2a-2l), $100 \mu \mathrm{L}$ MTT ( $5 \mathrm{mg} / \mathrm{mL}$ in PBS) was added to each well. Cells were incubated at $37{ }^{\circ} \mathrm{C}$ for $30 \mathrm{~min}$, dimethyl sulfoxide (DMSO) was added to dissolve the formazan crystals, and the absorbance was measured at $560 \mathrm{~nm}$ using a microplate reader a (Molecular Devices Co., Sunnyvale, CA, USA).

Measurements of Melanin Content. Cells $\left(2 \times 10^{4}\right.$ cells/ $\mathrm{mL}$ ) were seeded into 24 -well plates and dicinnamoylamide derivatives were added in triplicate. The medium was changed daily and after $4 \mathrm{~d}$ of culture, the cells were lysed with $0.1 \mathrm{~mL}$ of $1 \mathrm{~N} \mathrm{NaOH}$. Then $100 \mu \mathrm{L}$ of each crude cell extract was transferred to a 96-well plate. Relative melanin content was measured at $400 \mathrm{~nm}$ with a microplate reader (Molecular Devices).

Acknowledgments. This work was supported by the small and medium business technology innovation development project (S2048552) of the Korea small and medium business administration.

\section{References}

1. Piley, P. A. Pigment Cell Res. 2003, 16, 548.

2. Que, S. K.; Bergstrom, K. G. J. Drugs Dermatol. 2009, 8, 879.

3. (a) Sanchez-Ferrer, A.; Rodriguez-Lopez, J. N.; Garcia-Canavas, F.; Garcia-Carmona, F. Biochim. Biophys. Acta 1995, 1247, 1. (b) Seo, S. Y.; Sharma, V. K.; Sharma, N. J. Agric. Food Chem. 2003, 51, 2837. (c) Osaki, S. Arch. Biochem. Biophys. 1963, 100, 378.

4. (a) Stratford, M. R. L.; Ramsden, C. A; Riley, P. A. Bioorg. Med. Chem. 2012, 20, 4364. (b) Guevara, I. L.; Pandya, A. G. Int. J. Dermatol. 2003, 42, 966.

5. Kim, D. S.; Kim, S. Y.; Park, S. H.; Choi, Y. G.; Kwon, S. B.; Kim, M. K.; Na, J. I.; Youn, S. W.; Park, K. C. Biol. Pharm. Bull. 2005, $28,2216$.

6. (a) Lim, Y. J.; Lee, E. H.; Kang, T. H.; Ha, S. K.; Oh, M. S.; Kim, M. S.; Yoon, T. J.; Kang, C.; Park, J. H.; Kim, S. Y. Arch. Pharm. Res. 2009, 32, 367. (b) Hu, Z. M.; Zhou, Q.; Lei, T. C.; Ding, S. F.; Xu, S. Z. J. Dermatol. Sci. 2009, 55, 179.

7. (a) Ohyama, Y.; Mishima, Y. Fragrance J. 1990, 6, 53. (b) Cabanes, J.; Chazarra, S.; Garcia-Carmona, F. J. Pharm. Pharmacol. 1994, 46, 982-985.

8. (a) Rho, H. S.; Ahn, S. M.; Yoo, D. S.; Kim, M. K.; Cho, D. H.; Cho, J. Y. Bioorg. Med. Chem. Lett. 2010, 20, 6569. (b) Ahn, S. M.; Rho, H. S.; Baek, H. S.; Joo, Y. H.; Hong, Y. D.; Shin, S. S.; Park, Y. H.; Park, S. N. Bioorg. Med. Chem. Lett. 2011, 21, 7466. (c) Rho, H. S.; Lee, C. S.; Ahn, S. M.; Hong, Y. D.; Shin, S. S.; Park, Y. H.; Park, S. N. Bull. Korean Chem. Soc. 2011, 32, 4411.

9. Westerhof, W.; Kooyers, T. J. J. Cosmet. Dermatol. 2005, 4, 55.

10. (a) Song, K.; An, S. M.; Kim, M.; Koh, J. S.; Boo, Y. C. J. Dermatol. Sci. 2011, 63, 17. (b) Fan, Q.; Jiang, H.; Yuan, E. D.; Zhang, J. X.; Ning, Z. X.; Qi, S. J.; Wei, Q. Y. Food Chem. 2012, 134, 1081. (c) An, S. M.; Lee, S. I.; Choi, S. W.; Boo, Y. C. Br. J. Dermatol. 2008, 159, 292.

11. Lo, Y. H.; Lin, R. D.; Lin, Y. P.; Liu, Y. L.; Lee, M. H. J. Ethnopharmacol. 2009, 124, 625.

12. Criton, M.; Le Mellay-Hamon, V. Biol. Pharm. Bull. 2011, 34, 420.

13. Rho, H. S.; Baek, H. S.; You, J. W.; Kim, S. J.; Kim, M. K.; Kim, D. H.; Chang, I. S. Bull. Korean Chem. Soc. 2007, 28, 837. 